DOI: 10.32844/2222-5374-2020-104-2.47

УДК: 343.98:351.741

Рудніченко О. М.,

здобувач навчально-наукового інституту права «ВНЗ «МАУП»

\title{
ОБСТАВИНИ, ЩО ПІДЛЯГАЮТЬ ВСТАНОВЛЕННЮ У КРИМІНАЛЬНИХ ПРОВАДЖЕННЯХ ЩОДО НЕЗАКОННОГО ПОЗБАВЛЕННЯ ВОЛІ АБО ВИКРАДЕННЯ ЛЮДИНИ
}

Актуальність статті полягає в тому, що виявлення наявності або відсутності ознак злочину, а також необхідних обставин, що підлягають доказуванню у кримінальному провадженні, у правоохоронній практиці здійснюється поетапно. Звідси у структурі окремої криміналістичної методики розслідування кримінальних правопорушень особливого значення набуває періодизація етапів розслідування. При цьому до поняття «етап розслідування» включається взаємопов'язана система дій, об'єднаних єдністю завдань, умовами розслідування, специфікою криміналістичних прийомів. У той же час, органи досудового розслідування під час розслідування кримінальних проваджень мають дотримуватися встановленого кримінальним процесуальним законом порядку. У теорії кримінального процесу діяльність органів досудового розслідування поділяється на етапи, які називаються стадіями кримінального процесу. Першою стадією є досудове розслідування, на якій виникають кримінальні процесуальні відносини між учасниками кримінального процесу. У статті доведена обов'язковість встановлення події кримінального правопорушення (n. 1 ч. 1 cm. 91 КПК України), зокрема: факт учинення незаконного позбавлення волі або викрадення людини із застосуванням насильства; шантажу; обману; погрози; вчинення щодо малолітнього або з корисливих мотивів, групою осіб, із застосуванням зброї, або здійснюване протягом тривалого часу; коло осіб, причетних до вчинення злочину (прізвище, ім'я, по батькові, рік, місяць, день і місце народження, громадянство, національність, освіта, сімейний стан, наявність судимості, місце роботи, рід занять або посада, місце проживання, стан здоров'я, рівень ї̈ фізичного і розумового розвитку, наявність співучасників, форма їх співучасті); мотив та мета вчинення злочину; обставини зникнення, викрадення; час, місце та спосіб зникнення, викрадення; умови повернення (грошові кошти, транспортний засіб, нерухоме майно, певні послуги тощо), час, місце, сума та спосіб здійснення оплати (готівка, банківський переказ); вік потерпілого (число, місяџь, рік народження), стан здоров'я та загального розвитку дитини; вид та умови утримання, наслідки, чи застосовувались погрози, зброя до потерпілого (вид та характер). На матеріалах практики підтверджено обов'язковість встановлення форми вини, мотиву і мети правопорушника (учасників злочинної групи).

Ключові слова: людина, незаконне позбавлення волі, викрадення, розслідування, кримінальне провадження. 
Актуальність теми. Виявлення наявності або відсутності ознак злочину, а також необхідних обставин, що підлягають доказуванню у кримінальному провадженні, у правоохоронній практиці здійснюється поетапно. Звідси у структурі окремої криміналістичної методики розслідування кримінальних правопорушень особливого значення набуває періодизація етапів розслідування. При цьому до поняття «етап розслідування» включається взаємопов'язана система дій, об'єднаних єдністю завдань, умовами розслідування, специфікою криміналістичних прийомів.

У той же час, органи досудового розслідування під час розслідування кримінальних проваджень мають дотримуватися встановленого кримінальним процесуальним законом порядку. У теорії кримінального процесу діяльність органів досудового розслідування поділяється на етапи, які називаються стадіями кримінального процесу. Першою стадією $\epsilon$ досудове розслідування, на якій виникають кримінальні процесуальні відносини між учасниками кримінального процесу.

Виклад основного матеріалу. Досудове розслідування - стадія кримінального провадження, яка починається 3 моменту внесення відомостей про кримінальне правопорушення до Єдиного реєстру досудових розслідувань (ЄРДР) і закінчується закриттям кримінального провадження або направленням до суду обвинувального акта, клопотання про застосування примусових заходів медичного або виховного характеру, клопотання про звільнення особи від кримінальної відповідальності (п. 5 ч. 1 ст. 3 КПК України). Досудове слідство - форма досудового розслідування, в якій здійснюється розслідування кримінальних правопорушень (п. 6 ч. 1 ст. 3 КПК України). Дізнання - форма досудового розслідування, в якій здійснюється розслідування кримінальних проступків (п. 4 ч. 1 ст. 3 КПК України) [1; 2, с. 214].

Не вдаючись до наукового тлумачення досудового розслідування, зазначимо, що його поняття безпосередньо визначено в п. 5 ч. 1 ст. 3 КПК України і означає стадію кримінального провадження, яка починається 3 моменту внесення відомостей про кримінальне правопорушення до ЄРДР і закінчується закриттям кримінального провадження або направленням до суду обвинувального акта, клопотання про застосування примусових заходів медичного або виховного характеру, клопотання про звільнення особи від кримінальної відповідальності [1].

Найбільш важливими завданнями початкового етапу $\epsilon$ такі: 1) орієнтування особи, що проводить розслідування, в усіх обставинах тієї події, яку йому належить розслідувати, з'ясування фактів, які повинні бути досліджені у кримінальному провадженні, отримання вихідних даних з метою розгорнутого планування розслідування; 2) збирання та фіксація доказів, які упродовж невеликого проміжку часу можуть бути втрачені; 3) встановлення місцеперебування особи-зниклого. А вже під час наступного етапу розслідування здійснюється збирання, перевірка та оцінка доказів з метою повного встановлення усіх обставин кримінального провадження [3, с. 333-334].

Структуру початкового етапу становлять: здійснення організаційних заходів - планування початку розслідування, висунення версій, вибір форм 
взаємодії з особами, які допомагають у вирішенні завдань початкового етапу, а також прийняття процесуальних і організаційних рішень; початкові слідчі (розшукові) дії (СРД), спланованість і послідовність яких залежить від типових слідчих ситуацій і криміналістичної характеристики злочину, які допомагають у вирішенні завдань початкового етапу [4, c. 11].

Як показало вивчення слідчої практики, одним із найважливіших чинників, які забезпечують успішне розслідування кримінальних проваджень про насильницьке зникнення людини, $є$ їх негайне внесення до ЄРДР, що прямо залежить від своєчасного повідомлення або виявлення ознак вчиненого злочину. У зв'язку з цим особливої актуальності і значущості, на наш погляд, набуває етап збору та перевірки матеріалів. Особливість даного етапу багато в чому визначається кримінальноправовою природою розглянутого злочину і тим, що дії, які становлять цю стадію спрямовані на встановлення місцеперебування особи.

До особливостей початкового етапу розслідування незаконного позбавлення волі або викрадення людини варто віднести:

розслідування злочинів проводиться, зазвичай, в умовах дефіциту вихідної інформації та часу для прийняття процесуальних й організаційних рішень;

можливості одержання доказової інформації процесуальним шляхом, як правило, дуже обмежені, оскільки невідомі місце викрадення й утримання жертви, очевидці цього злочину і місце знаходження слідів злочинного посягання;

з'ясування місця перебування викраденої (незаконно утриманої) особи, пошук і викриття викрадачів вимагають взаємодії і координації спільних зусиль слідчих, працівників прокуратури, оперативних співробітників органів Національної поліції України, у тому числі спеціальних підрозділів, а також Служби безпеки України;

встановлення місця перебування потерпілого, його звільнення i затримання викрадачів (утримувачів) забезпечуються переважно негласними слідчими (розшуковими) діями, оперативно-технічними та оперативно-розшуковими заходами, які характеризуються конспіративністю дій відповідних суб’єктів, їх активністю в проведенні зазначених заходів, що обумовлено прагненням зберегти життя і здоров'я утримуваній злочинцями особі;

необхідність обов'язкового опрацювання, як однієї з робочих версій самовикрадення особи;

при розслідуванні злочинів даного виду особливу криміналістичну роль відіграють час, місце і спосіб передачі матеріальних цінностей чи прав на майно, відомості про які співробітники правоохоронних органів одержують з повідомлень осіб, яким пред’явлені відповідні вимоги. Ці відомості необхідно максимально використовувати для: підготовки технічних засобів фіксації обставин вчиненого злочину; розробки операції із забезпечення безпеки жертви, її близьких і збереження майна; вивчення особи жертви і їі оточення; встановлення і вивчення осіб викрадачів та їх оточення; здійснення інших підготовчих дій, спрямованих на затримання і викриття злочинців [5, с. 82]. 
Після переходу воєнного конфлікту в фазу низької інтенсивності кількість зникнень зменшилася, але все одне вони залишаються частими. Про долю зниклих не повідомляється. Лише через певний період, який може тривати від декількох годин до декількох місяців або навіть більше, зниклих впізнають в тілах загиблих із слідами насильницької смерті, або з'ясовується, що зниклий знаходиться в місці позбавлення волі під контролем [6].

З урахуванням вищевикладеного, діяльність слідчого на початковому етапі розслідування кримінальних правопорушень, передбачених ч. 1 ст. 214 КПК України буде включати в себе:

1) внесення відомостей до ЄРДР.

2) оцінку інформації, що надійшла про кримінальне правопорушення;

3) перевірку заяви, повідомлення;

Аналіз слідчої практики показує, що інформація про злочинне діяння за ознаками ст. 146 КК України надходить від рідних та близьких потерпілого (57 \%); громадськості, моніторингових візитів до населених пунктів вздовж лінії розмежування (23 \%); виявлення ознак злочину безпосередньо правоохоронними органами (8\%); повідомлення (заяви) знайомих, колег по службі, партнерів по бізнесу потерпілого (8 \%); повідомлення службових осіб державних органів, підприємств, організацій (2 \%); жертви викрадення (незаконно позбавленої волі) після ії̈ звільнення про вчинений відносно неї злочин (2 \%).

За даними проведеного нами дослідження, повідомлення про вчинення цього злочину до органів поліції у 57 \% випадків надходять від родичів зниклих та інших громадян, яким яким-небудь чином стало відомо про зникнення, що є приводом до внесення відомостей до ЄРДР.

При виявленні ознак злочину безпосередньо працівником правоохоронного органу, складається рапорт із зазначенням відомостей, які передбачені ч. 5 ст. 214 КПК України. Рапорт передається керівнику органу досудового розслідування, який визначає попередню правову кваліфікацію і доручає слідчому провести досудове розслідування.

Так, слідчий, прокурор невідкладно, але не пізніше 24 годин після подання заяви, повідомлення про вчинене кримінальне правопорушення або після самостійного виявлення ним з будь-якого джерела обставин, що можуть свідчити про вчинення кримінального правопорушення, зобов'язаний внести відповідні відомості до ЄРДР та розпочати розслідування (ч. 1 ст. 214 КПК України) [1; 7].

До ЄРДР вносяться відомості про: 1) дату надходження заяви, повідомлення про кримінальне правопорушення або виявлення з іншого джерела обставин, що можуть свідчити про вчинення кримінального правопорушення; 2) прізвище, ім'я, по батькові (найменування) потерпілого або заявника; 3) інше джерело, з якого виявлені обставини, що можуть свідчити про вчинення кримінального правопорушення; 4) короткий виклад обставин, що можуть свідчити про вчинення кримінального правопорушення, наведених потерпілим, заявником чи виявлених 3 іншого джерела; 5) кваліфікація кримінального правопорушення за ст. 146-1 КК України; 6) прізвище, ім'я, по батькові та посада службової особи, яка внесла відомості до реєстру, а також слідчого, прокурора, який 
вніс відомості до реєстру та/або розпочав досудове розслідування; 7) інші обставини, передбачені положенням про ЄРДР $[1 ; 8]$. У ЄРДР автоматично фіксується дата внесення інформації та присвоюється номер кримінального провадження.

Внесення відомостей до ЄРДР визначає момент початку досудового розслідування. Одержавши від керівника доручення про проведення досудового розслідування, слідчий відразу, не зволікаючи, повинен внести відомості до ЄРДР.

Єдиною процесуальною дією, яку КПК дозволяє проводити у невідкладних випадках до моменту внесення відомостей до ЄРДР, є огляд місця події. Під невідкладними випадками розуміється ситуація, за якої зволікання з проведенням огляду місця події може призвести до втрати матеріальних слідів кримінального правопорушення, знарядь та засобів його вчинення, втрати інформації про осіб, що його вчинили. У виняткових ситуаціях, коли місце утримання жертви вже відоме і потрібно вжити невідкладних заходів до звільнення викраденого і затримання злочинців оперативним черговим вживаються заходи щодо направлення СОГ на місце події (ч. 3 ст. 214 КПК України).

Досліджуючи ст. 214 КПК України, Ю. П. Аленін запропонував передбачити: докладнішу регламентацію порядку прийняття, реєстрації заяв чи повідомлень про діяння, визначені законодавством про кримінальну відповідальність; строки їх розгляду (не менше ніж десять діб); можливість перевірки заяв чи повідомлень, визначення процесуальних засобів таких дій; обов'язок службових осіб приймати процесуальне рішення у формі винесення постанови слідчим/прокурором про початок досудового розслідування або про відмову в ньому; обставини, які виключають проведення досудового розслідування; право на оскарження до прокурора чи слідчого судді рішень про початок досудового розслідування та про відмову в ньому [9, с. 237-238].

При надходженні поштовою кореспонденцією до правоохоронного органу заяви (повідомлення) про кримінальне правопорушення за ст. 146 КК України відділ документального забезпечення та режиму після реєстрації вхідної кореспонденції доповідає ії начальникові органу поліції. Слідчий вносить заяву (повідомлення) до ЄРДР (ст. 214 КПК). За необхідності чергова частина направляє на місце події слідчо-оперативну групу (далі - СОГ), яка проводить огляд та про результати старший СОГ доповідає рапортом для внесення відповідних відомостей до ЄРДР. Якщо виїжджати на місце події немає необхідності, керівник досудового розслідування визначає слідчого, який здійснюватиме досудове розслідування (ч. 1 ст. 214 КПК).

Відповідно до ч. 2 ст. 91 КПК України, доказування полягає в збиранні, перевірці та оцінці доказів з метою встановлення обставин, що мають значення для кримінального провадження.

Категорія «доказування» $\epsilon$ однією 3 ключових у кримінальному процесі. Розглядаючи зміст кримінального процесуального доказування, більшість авторів виокремлює два його види: доказування як пізнання фактичних обставин кримінального правопорушення і доказування як перевірка певної слідчої версії. 
Кримінальне процесуальне доказування не є науковим, оскільки воно: не має на меті пізнання закономірностей розвитку природи та суспільства (пізнавальну діяльність спрямовано на з'ясування обставин конкретного діяння); обмежене процесуальними строками; його здійснюють спеціальні суб’єкти за допомогою специфічних засобів у визначеній кримінальним процесуальним законом формі.

Обов'язок доказування обставин, передбачених ст. 91 КПК України, за винятком випадків, визначених у ч. 2 ст. 92 КПК України, покладено на слідчого, прокурора та, в установлених КПК України випадках, - на потерпілого. Обов'язок доказування належності та допустимості доказів, даних щодо розміру процесуальних витрат й обставин, які характеризують обвинуваченого, покладено на сторону, що їх подає.

Значення кримінального процесуального доказування полягає в такому: 1) правильне його здійснення дає змогу забезпечити реалізацію прав і законних інтересів усіхучасників кримінального процесу; 2) питання, які постають під час кримінального провадження, можна вирішити лише на підставі достовірно встановлених у процесі доказування обставин; 3) участь заінтересованих суб'єктів у доказуванні є гарантією реалізації принципів кримінального процесу; 4) докази є підставою для прийняття процесуальних рішень у кримінальному провадженні.

3 огляду на те, що в нашій державі оперативно-розшукова діяльність фактично включена до кримінального процесу, значно розширено арсенал процесуальних дій, передусім завдяки запровадженню такої правової категорії, як «негласні слідчі (розшукові) дії» (які $€$ «модернізованими» оперативно-розшуковими заходами; запровадження цього інституту рекомендувала низка міжнародних організацій, серед яких Рада Європи).

У ч. 1 ст. 91 КПК України викладено перелік обставин, що належать до предмета доказування в кримінальному провадженні, як сукупності фактів і обставин об'єктивної дійсності, які мають матеріально-правове, цивільно-правове, кримінальне процесуальне значення та є необхідними й достатніми фактичними обставинами для вирішення кримінального провадження по суті. Ця норма відповідає на запитання, встановлення яких фактів й обставин є метою доказування: 1) подія кримінального правопорушення (час, місце, спосіб та інші обставини вчинення кримінального правопорушення); 2) винуватість обвинуваченого в учиненні кримінального правопорушення, форма вини, мотив і мета вчинення кримінального правопорушення; 3) вид і розмір шкоди, завданої кримінальним правопорушенням, а також розмір процесуальних витрат; 4) обставини, які впливають на ступінь тяжкості вчиненого кримінального правопорушення, характеризують особу обвинуваченого, обтяжують чи пом'якшують покарання, які виключають кримінальну відповідальність або є підставою для закриття кримінального провадження; 5) обставини, що є підставою для звільнення від кримінальної відповідальності або покарання; 6) обставини, які підтверджують, що гроші, цінності й інше майно, які підлягають спеціальній конфіскації, одержані внаслідок учинення кримінального правопорушення та/або є доходами від такого майна, або призначалися (використовувалися) для схиляння особи до вчинення кримінального правопорушення, фінансування та/або матеріального забезпечення кримі- 
нального правопорушення чи винагороди за його вчинення, або є предметом кримінального правопорушення, зокрема пов'язаного з їх незаконним обігом, або підшукані, виготовлені, пристосовані чи використані як засоби або знаряддя вчинення кримінального правопорушення; 7) обставини, що $є$ підставою для застосування до юридичних осіб заходів кримінальноправового характеру.

Встановити зазначені обставини (їх доказування $\epsilon$ обов'язком сторони обвинувачення, зокрема слідчого та прокурора), згідно з вимогами ч. 2 ст. 9, ст. 25, ч. 1 ст. 92 КПК України, можна лише за допомогою доказів, визначених у ст. 84 КПК України (показань, речових доказів, документів, висновків експертів) [10, с. 28]. Правильне та своєчасне визначення предмета доказування позитивно позначається на організації досудового розслідування. Діяльність слідчого та прокурора стає послідовнішою, цілеспрямованішою й ефективнішою. Надмірне розширення предмета доказування призводить до того, що невиправдано затягується час досудового розслідування, збільшуються процесуальні витрати, зростає навантаження на всіх його учасників через зайве нагромадження відомостей про факти, які не мають істотного значення для кримінального провадження. Безпідставне обмеження предмета доказування спричиняє неповноту й однобічність досудового розслідування, створюючи враження про упереджене ставлення слідчого та прокурора до підозрюваного. У зв'язку із цим виникають сумніви щодо результатів досудового розслідування, а доказів виявляється недостатньо для того, щоб суд постановив справедливий вирок [10, с. 29].

За даними здійсненого опитування, проблеми досудового розслідування злочинів, пов'язаних із незаконним позбавленням волі або викраденням людини, зумовлені: складністю установлення мети та мотиву підозрюваного у випадках, коли не висунуто прямих погроз або вимог до вчинення або після вчинення викрадення людини (64,0 \%); складністю виявлення слідів, які вказують на причетність певних осіб до вчинення викрадення людини (сліди можуть бути знищені злочинцями, свідками, а в окремих випадках - учасниками слідчого огляду, які не акцентували на них уваги і належно їх не дослідили) (52,0 \%); протидією розслідуванню - від намагань перешкодити кримінальному провадженню аж до погроз учинити насильницькі дії щодо потерпілого (-их), якщо не буде виконано їх вимоги $(39,0 \%) ;$ об'єктивними труднощами в роботі зі свідками, що спричинені як психологічним шоком, панікою, так й особливостями людського сприйняття $(38,0$ \%); створенням несприятливого емоційного стану, що породжує чутки, викривлення інформації, домисли з боку свідків, а також безпідставне визнання провини деякими психічно неврівноваженими особами, які прагнуть привернути до себе увагу, чим заважають процесу розкриття злочину та кримінальному провадженню (31,0%). Значна кількість проблем досудового розслідування стосується саме обставин, що становлять предмет доказування, визначених ст. 91 КПК України. стадії:

Таким чином, зміст перевірки повідомлень можна розділити на три

1) з'ясування обставин зникнення;

2) висування, виходячи з цих обставин, версій про причини зникнення; 
3) перевірка цих версій.

Для з'ясування обставин зникнення, великого значення набуває одержання даних про особу-зниклого та її прикмети, стосунки 3 оточуючими, стану перед зникненням. При цьому встановлюються питання, що стосуються комунікативних якостей передбачуваної жертви: товариськості, замкнутості, здатності швидко зав'язувати знайомства, звичайне коло спілкування, наявність або відсутність близьких друзів, приятелів, схильність до проведення часу з випадковими людьми і т.д.

Підводячи підсумки сказаного, виділимо, що відправним моментом встановлення інформації про розслідуваннязлочиннихдій передбаченихст. 146 КК України є етап з'ясування обставин правопорушення, передбачених нормами законодавства, застосування після внесення до ЄРДР відомостей про злочин процесуальних засобів щодо встановлення місцеперебування жертви посягання, а також особи (осіб), яка ймовірно вчинила це правопорушення (строки цього етапу кримінальним процесуальним законом не встановлені), оголошення особи у міжнародний розшук, проведення усіх СРД та негласних слідчих (розшукових) дій, накопичення достатньої кількості доказової інформації, що забезпечує подальше швидке та повне розслідування кримінального правопорушення [11, с. 271].

На початковому етапі розслідування слідчий у своєму розпорядженні повинен мати такі матеріали: рапорт про виявлення кримінального правопорушення; зареєстроване повідомлення про початок досудового розслідування; доручення про проведення досудового розслідування; детальні відомості про те, при яких обставинах було вчинено кримінальне правопорушення; протокол огляду місця події; протокол допиту свідків, очевидців вчинення злочину.

\section{СПИСОК ВИКОРИСТАНИХ ДЖЕРЕЛ}

1. Кримінальний процесуальний кодекс України: Закон України від 13.04.2012 р. Верховна Рада України. URL: http://zakon3.rada.gov.ua/laws/ show/4651-17.

2. Кримінальний процес: підручник / за заг. ред. В.В. Коваленка, Л.Д. Удалової, Д.П. Письменного. Київ: Центр учбової літератури, 2013. $544 \mathrm{c}$.

3. Белкин Р. С. Очерки криминалистической тактики: учеб. пособ. Волгоград: ВСШ МВД РФ, 1993. 200 с.

4. Ищенко Е. П. Проблемы первоначального этапа расследования преступлений / науч. ред. И. Ф. Герасимов. Красноярск: Краснояр. ун-та, 1987. $168 \mathrm{c.}$

5. Олішевський В. В. Особливості виявлення ознак викрадення людини, вчиненого з корисливих мотивів. Вісник Національного університету внутрішніх справ. 2004. Вип. 26. С. 79-86.

6. Насильницькі зникнення в Україні та зникнення безвісти під час воєнного конфлікту. Харків: 2018. 48 с.

7. Про затвердження Інструкції з організації взаємодії органів досудового розслідування з іншими органами та підрозділами Національної поліції України в запобіганні кримінальним правопорушенням, їх виявленні та розслідуванні: наказ МВС України від 07 лип. 2017 р. 
№ 575. Верховна Рада України. URL: https://zakon.rada.gov.ua/go/ z0937-17

8. Порядок ведення єдиного обліку в органах (підрозділах) поліції заяв і повідомлень про кримінальні правопорушення та інші події: наказ MBC України від 08 лют. 2019 р. № 100. Верховна Рада України. URL: https:// zakon.rada.gov.ua/laws/show/z0223-19

9. Аленін Ю. П. Особливості відкриття матеріалів іншій стороні за новим КПК України. Актуальні проблеми кримінального права, процесу та криміналістики : матеріали IV міжнар. наук.-практ. конф..Одеса, 2012. C. 237-240.

10. Баулін О. В. Обставини, що підлягають встановленню під час досудового розслідування. Науковий часопис Національної академії прокуратури України. 2015. № 4. С. 28-38.

11. Войтович $€$. М. Криміналістична характеристика обстановки вчинення насильницького зникнення людини. Актуальні питання виявлення та розкриття злочинів Національною поліцією: вітчизняний та зарубіжний досвід. матеріали Міжнар. наук.-практ. круглого столу (Київ, 19 лют. 2020 р.). Київ : Нац. акад. внутр. справ, 2020. С. 270-273.

\section{O. Rudnichenko}

\section{CIRCUMSTANCES TO BE ESTABLISHED IN CRIMINAL PROCEEDINGS REGARDING ILLEGAL DEPRIVATION OF FREEDOM OR KIDNAPPING}

The relevance of the article is that the detection of the presence or absence of signs of a crime, as well as the necessary circumstances to be proved in criminal proceedings, in law enforcement practice is carried out in stages. Hence, in the structure of a separate forensic methodology of investigation of criminal offenses, the periodization of stages of investigation acquires special significance. In this case, the concept of «stage of investigation» includes an interconnected system of actions, united by the unity of tasks, the conditions of the investigation, the specifics of forensic techniques. At the same time, the bodies of pre-trial investigation during the investigation of criminal proceedings must follow the procedure established by the criminal procedure law. In the theory of criminal procedure, the activities of pre-trial investigation bodies are divided into stages, which are called stages of the criminal process. The first stage is a pre-trial investigation, in which criminal procedural relations arise between the participants in the criminal proceedings. The article proves the obligation to establish the event of a criminal offense (paragraph 1, part 1 of Article 91 of the CPC of Ukraine), in particular: the fact of committing illegal imprisonment or kidnapping with violence; blackmail; deception; threats; an act against a minor or for selfish motives, by a group of persons, with the use of a weapon, or committed for a long time; circle of persons involved in the crime (surname, name, patronymic, year, month, day and place of birth, citizenship, nationality, education, marital status, criminal record, place of work, occupation or position, place of residence, status health, the level of her physical and mental development, the presence of accomplices, the form of their complicity); motive and purpose of the crime; circumstances of disappearance, abduction; time, place 
and method of disappearance, abduction; terms of return (cash, vehicle, real estate, certain services, etc.), time, place, amount and method of payment (cash, bank transfer); age of the victim (date, month, year of birth), state of health and general development of the child; type and conditions of detention, consequences, whether threats were used, weapons to the victim (type and nature). The materials of the practice confirm the obligation to establish the form of guilt, motive and purpose of the offender (members of the criminal group).

Keywords: person, illegal imprisonment, abduction, investigation, criminal proceedings. 